\title{
EVOLUTION OF CONTEMPORARY JAPANESE ART MUSEUMS THROUGH THE ANALYSIS OF THE PLAN CONFIGURATION
}

\author{
Architectural Design of Japanese Art Museums since the Second World War \\ 現代日本美術館建築に扮ける平面構成の分析による歴史的変遷に関する研究 \\ 〜 第二次世界大戦後の日本の美術館を対象として〜 \\ Helena MACHIN* and Jorge ALMAZAN** \\ マチン エレナ, アルマザン ホルヘ
}

\begin{abstract}
Art museums are taken in this investigation as an effective sample to analyze architectural design in Japan of the last 65 years. First, through the analysis of the configuration in plan of a selection of 102 cases, this study offers two classifications based on 1) exterior boundary, and 2) interior layout. Second, this study discusses connections between these two classifications, and suggest eight patterns, which help to understand the evolution of architectural design of Japanese art museums through time.
\end{abstract}

Keywords: Japan, Art museum, Plan configuration, Typology, Contemporary architecture 日本, 美術館, 平面構成, 類型学, 現代建築

\section{Introduction}

\subsection{Background and research question}

This study focuses on Japanese art museums built after the Second World War. To nowadays, museum buildings have been characterized for having freer shape than other building types such as offices or houses due to the relative flexibility of the program exhibition requirements. In addition, most of art museums have a larger budget, and architects are encouraged testing how far they can push the limits of their abilities in architectural design. ${ }^{1}$ Architects have always been trying to create a different approach to architectural design with the goal of providing differentiation and identity to the building. Changes in the use of material, the shape of the building, its organization or configuration are some of the parameters employed by architects to reach this differentiation.

At the beginning of the 1930s, an identification of "Japan-ness" 2 to an external gaze began, at the same time when Japan adopted Western modernism in architecture. Since then, the debate of the "Japanese taste" in architectural design remains in the studies of Japanese architecture. In this study Japanese architecture is analyzed as an example of a particular way of thinking architecture, contributing also to enlarge current studies about contemporary architecture.

This investigation takes art museums as an effective sample of architectural design processes of the last 65 years in Japan. The goal of this research is to establish a classification of Japanese contemporary museums, describing the characteristics of these new types that have emerged over the past years. For this purpose, this study tries to identify some of the elements and characteristics of the contemporary Japanese art museums, and also to establish the relationships between two aspects: the external boundary and the interior layout. The reason why we focused on these two aspects is because they are both fundamental and, at the same time, they can be studied independently. Also, especially in the last years, there is an increasing use of innovative exterior forms, which often contain interior layouts that do not necessary show the same degree of innovation. For example, the main facade of The Tokyo National Art Center has an irregular form but its interior configuration has a front-back hierarchical structure, which has a long tradition in architecture. On the contrary, we can find museums like the 21st Century Museum of Contemporary Art with a regular external geometry, but presenting innovation in the interior conditions with an isotropic layout. Therefore, we consider the comparison of these aspects (external boundary and interior layout) especially relevant to understand the evolution of Japanese art museums until nowadays.

\subsection{Methodology and sources}

Due to the complexity of architecture, graphic analysis is a method used
* Ph. D. Candidate, Graduate School of Science and Technology, Keio Univ., B. A. Eng.

** Assist. Prof., Dept. of System Design Engineering, Fac. of Science \& Technology, Keio Univ. Licensed Architect, Dr. Eng.
慶應義塾大学大学院理工学研究科 博士後期課程・学士 (工学) 慶應義塾大学理工学部システムデザイン工学科 専任講師・博士(工学) 
to express architectural form, concepts and systems in a reduced way. Many architects theorized about architectural concepts by using this analytical method. In the 1920s, Alexander Klein ${ }^{3}$ published some of his most known works where he established a graphic method to study typological classification and make comparison and validations between different buildings. Other architects such as Christopher Alexander ${ }^{4}$, Peter Eisenman ${ }^{5}$ or John Hejduk ${ }^{6}$ are early examples who used graphic analysis and architectural diagrams to express concepts and architectural systems.

In Japan, there are several studies about architectural composition. The methodology described by Kazunari Sakamoto et $\mathrm{al}^{7}$ is used for study cases analysis and typology creation. For this study, we follow this methodology trying to adapt it to our specific goals.

In order to achieve a clear understanding of the cases and their design concepts, this study focuses on formal aspects and does not consider intangible aspects such as materiality, or light conditions, in order to identify patterns in geometry, hierarchy or orientation. The analysis of the geometry of the building plan, and the creation of conceptual diagrams, is one way to show how new architectural concepts can be derived. In this paper we use the building plan analysis because, in most of the cases, the plan conveys the main organizing strategy of a building. It is full of clues about the designer's values and attitudes toward theories of order, methods of construction. The idea is not to use the plan just as a set of data, but also of values, ideas and analogies that had shaped the building in a particular way.

The conceptual diagrams are created from every case like a parti diagram. Hejduk ${ }^{6}$ defines a parti as "a diagram that delineates the dominant organizational or formal concept governing an architectural scheme". The purpose of this study in plan is not to demonstrate the abstract perfection of ideal form itself but a schematic design process through which the creative intention can embody the complex relation between concept and form, and the internal organization.

For this paper we analyze only one floor for each museum that can be consider that parti of the building. Some museums are formed by a single floor plan (21 of 102). When there is a case formed by more than one floor, the plan to analyze is the one containing the largest exhibition area. In most of the cases ( 87 of 102), the access floor plan contains the largest exhibition area.

\subsection{Object of study}

102 samples (Table 1) have been selected from the period after the Second World War. These buildings are published in the questionnaires of

Table 1 Cases list and code

\begin{tabular}{|c|c|c|c|c|c|c|c|c|c|}
\hline \multicolumn{2}{|c|}{ No. Year } & \multirow{2}{*}{ Architecture Name } & Architect & \multirow{2}{*}{ Code } & \multicolumn{3}{|c|}{ No. Year Architecture Name } & \multirow{2}{*}{ Architect } & Code \\
\hline 1 & 1959 & & Yoshiro Taniguchi & & 53 & 1995 & Nariwa Munic. Mus. & & 110-DLpe \\
\hline 2 & 1964 & Okayama Prefectural Mus. of Art & Kunio Maekawa & 111-DLpee & 54 & 1996 & Toyota Munic. Mus. of Art & Taniguchi Yoshio & 111-ERpeS \\
\hline 3 & 1966 & Nagano Prefectural Shinano Art Mus. & Nikken sekkei & 111-ERpel & 55 & 1996 & Anpanman Mus. & Furuya Nobuaki & 110-DLpe \\
\hline 4 & 1973 & Tochigi Prefectural Mus. of Fine Art & Kiyoshi Kawasaki & 101-ELpee & 56 & 1996 & Kampo Mus. in Shiga & Team ZOO & 100-DLppee \\
\hline 6 & 1973 & Nara National Mus. & Zyuzo Yoshimura & 111-ERpel & 58 & 1996 & Hamada Children'S Mus. of Art & Shin Takamatsu & 111-DLpep \\
\hline 7 & 1975 & Kitakyushu Municipal Mus. of Art & Arata Isozaki & 110-ERpeL & 59 & 1996 & Okazaki City Art Mus. & Kuryu Akira & $111-\mathrm{C} 2$ \\
\hline 8 & 1975 & The Mus. of Modern Art Gunma & Arata Isozaki & 111-DLpe & 60 & 1997 & Sakata City Mus. of Art & Ikehara Yoshiro & 111-ERpeS \\
\hline 9 & 1975 & Ikeda 20th Century Mus. & Takeyoshi Inoue & 101-DLpee & 61 & 1997 & Kumano Kodo Nakahechi Mus. & SANAA & $100-\mathrm{C} 2$ \\
\hline 10 & 1974 & Chiba Prefectural Mus. of Art & Ootaka Masato & 111-ERpel & 62 & 1997 & Chihiro Art Mus. Azumino & Naito Hiroshi & 111-ERpeS \\
\hline 12 & 1977 & Hokkaido Mus. of Modern Art & Minoru Ota & 111-ERpel & 64 & 1998 & Akino Fuku Mus. & F. Terunobu+Uchida Y. & 110-DLppe \\
\hline 13 & 1978 & Kumamoto Prefectural Mus. of Art & Kunio Maukawa & 111-DRpeC & 65 & 1998 & Tenshin Memorial Mus. of Art & Naito Hiroshi & 111-ERpeS \\
\hline 14 & 1978 & Iwasaki Art Mus. & Maki and associates & 111-ERpeL & 66 & 1998 & Sagawa Art Mus. & Takenaka corporation & 111-DRpeC \\
\hline 15 & 1979 & Shiseido Art House & Yoshio Taniguchi & 100-DLpee & 67 & 1998 & Daylight Mus. & Tadao Ando & 100-DLpep \\
\hline 16 & 1981 & The Shoto Mus. of Art & Seichi Shirai & 100-DLppe & 68 & 1999 & Shimane Art Mus. & Kikutake Kiyonori & 01-ERpel \\
\hline 17 & 1981 & Shizuoka Munic. Serizawa Keisuke Art Mus. & Seichi Shirai & 101-DLppee & 69 & 1999 & Nemunoki Art Mus. & Shigeru Ban & $101-\mathrm{A}$ \\
\hline 18 & 1982 & Japanese Ukiyo E Mus. & Kazuo Shinohara & 110-DLpe & 70 & 1999 & Univ. Art Mus., Tokyo & & \\
\hline 19 & 1982 & The Miyagi Mus. of Art & Kunio Maukawa & 111-DLpe & & & National Univ. of Fine Arts and Music & Sekkei & 111-ELpepe \\
\hline 20 & 1983 & The Mus. of Modern Art, Saitama & Kisho Kurokawa & 01-ERpeV & 71 & 1999 & Kirishima Art Hall & Kunihiko Hayakawa & 111-DLpee \\
\hline 21 & 1984 & Izunochohachi Mus. & Osamu Ishiyama & 100-ERpeV & 72 & 2000 & Bato Machi Hiroshige Mus. & Kuma Kengo & 111-DLpee \\
\hline 22 & 1984 & Tanimura Mus. & Murano Mori Associate & 100-ERpeS & 73 & 2001 & Tokyo National Mus. & & \\
\hline 25 & 1985 & Okanoyama Graphic Art Mus., Nishiwaki & Arata Isozaki & 01-ELpepe & 75 & 2002 & Gunma Mus. of Art, Tatebayashi & T.Takahashi+D.Kobo & 100-ERpeS \\
\hline 26 & 1986 & Setagaya Art Mus. & Syozo Uchii` & 111-ERpeL & 76 & 2002 & Pola Mus. of Art & Nikken Sekkei & $100-\mathrm{C} 1$ \\
\hline 27 & 1986 & The Tasaki Mus. of Art & Koji Hara & 101-ELpe.e & 77 & 2003 & The Mus. of Modern Art Hayama & AXS SATO INC & 111-ERpeL \\
\hline 28 & 1985 & Shizuoka Prefectural Mus. of Art & Shizuoka S. Rengou & 111-DLppe & 78 & 2004 & $21 \mathrm{st}$ Century Mus. of Contemp. Art & SANAA & $100-\mathrm{B}$ \\
\hline 29 & 1986 & The National Mus. of Modern Art, Kyoto & Fumihiko Maki & 111-DLpe & 79 & 2004 & Chichu Art Mus. & Ando Tadao & 110-DLppee \\
\hline 30 & 1987 & Nagoya City Art Mus. & Kisho Kurokawa & 01-DLppee & 80 & 2004 & Kagawa Prefectural Higashiyama & & \\
\hline 31 & 1989 & Iida City Mus. & Koji Hara & 101-DRpeC & & & Kaii Setouchi Art Mus. & Yoshio Taniguchi & 111-DLpe \\
\hline 32 & 1989 & Nakagawa Kazumasa Art Mus. & TAK Architects INC. & 111-ERpeS & 81 & 2004 & Ehon Mus. & Tadao Ando & $110-\mathrm{C} 2$ \\
\hline 33 & 1989 & Informel Nakagawamura Mus. & Kikou Mozuna & 100-DLpe & 82 & 2005 & ro Art Mu & Yokomizo Makoto & 111-DRpeC \\
\hline 34 & 1989 & Hiroshima City Mus. of Contemp. Art & Kisho Kurokawa & 100-ERpel & 83 & 2005 & Nagasaki Prefectural Mus. & Kuma K.+N. Sekkei & 111-ERpeV \\
\hline 35 & 1989 & Yokohama Mus. of Art & Kenzo Tange & $100-\mathrm{ERpeV}$ & 84 & 2005 & Kanno Mus. & Hitoshi Abe & $111-\mathrm{C} 1$ \\
\hline 36 & 1990 & Nagano Prefectural Shinano Art Mus., & & & 85 & 2006 & Aomori Mus. of Art & Aoki Jun & $100-\mathrm{C} 1$ \\
\hline & & Higashiyama Kaii Gallery & Yoshic & ERpeL & 86 & 2006 & Mus. & Tadao Ando & $101-\mathrm{C} 2$ \\
\hline 37 & 1990 & Kawamura Memorial Dic Mus. of Art & Ichiro Ebihara & RpeL & 87 & 2007 & Keyforest 871228 Keith Haring Mus. & Kitagawara Atsushi & 101-DLppee \\
\hline 38 & 1989 & Imaizumi Mus. & Hisao Kouyama & 100-DLpe & 88 & 2007 & Yokosuka Mus. of Art & Yamamoto Riken & 111-ERpeL \\
\hline 39 & 1991 & Autopolis Art Mus. & Hiroshi Naito & 111-ERpel & 89 & 2007 & Okinawa Prefectural Mus. \& Art Mus. & Ishimoto+Niki & 111-ERpeV \\
\hline 40 & 1992 & Naoshima Contemp. Art Mus. & Tadao Ando & 100-DLppe & 90 & 2007 & The National Art Center, Tokyo & Kurokawa Kishou & 01-DRpeC \\
\hline 41 & 1992 & Koriyama City Mus. of Art & awa $\mathrm{T}$. & 111-DRpeC & 91 & 2007 & Suntory Mus. of Art & Kengo Kuma & 111-DLpee \\
\hline 42 & 1992 & Shinsyu Takato Mus. of Art & Tadanaga Miyamoto & 100-DLpee & 92 & 2007 & Nemunoki Children Mus. & Terunobu Fujimori & 01-ELpepe \\
\hline 43 & 1993 & Shima Art Mus. & Hiroshi Naito & 111-DLppe & 93 & 2008 & Towada Art Centre & Nishizawa Ryue & 01-ERpeS \\
\hline 44 & 1993 & Jingu Mus. of Fine Arts & Hiroshi Ohe & 111-ELpe.e & 94 & 2008 & Hara Mus. Arc & Arata Isozaki & 110-ERpeV \\
\hline 45 & 1994 & Rias Ark Mus. & Osamu Ishiyama & 01-ERpeV & 95 & 2009 & Nezu & Kuma Kengo & 111-DLppe \\
\hline 49 & 1995 & Ehime Mus. of Science & Kurokawa Kisho & 100-DLppe & 99 & 2010 & Mus. of The Light & Tadao Ando & 111-DLppe \\
\hline 50 & 1995 & Suntory Mus. & Ando Tadao & 100-DLppe & 100 & 2011 & Hiroshi Senju Mus. Karuizawa & Nishizawa Ryue & $00-\mathrm{A}$ \\
\hline 51 & 1995 & Miyazaki Prefectural Art N & S.Okada+.Sekkei & 100-ERpel & 101 & 2011 & Ken Iwata Mother and Child Mus. & Toyo Ito & $00-\mathrm{A}$ \\
\hline 52 & 1995 & Shoji Ueda Mus. of Photography & Takamatsu Shin & 100-DLppe & 102 & 2012 & Akita Mus. of Art & Tadao Ando & 101-DLpep \\
\hline
\end{tabular}


Table 3 Concepts for interior conditions

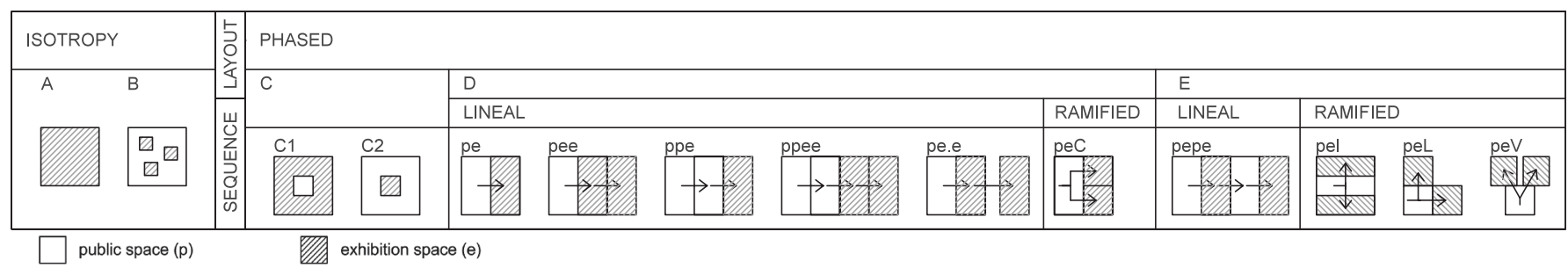

are multiple books about museums around the world including Japanese examples ${ }^{8}$, but they are mostly just photographic collections without any analytical classification. We can also find popular media publications about Japanese museums ${ }^{9}$. There are also several studies on Japanese contemporary architecture and museum typology that show a relation with this paper. Nakai, Moriyama and Sakamoto ${ }^{10}$ focus their research on exterior conditions. Using the architectural composition methodology described in "methodology and sources" part (sec. 1.2), they make a typology classification based on museum elements composition, the relation with the conditions of location, and the external spatial composition in terms of the public characteristics of the typology. In the case of Koike and Nakagawa ${ }^{11}$, they focus their research on interior conditions using Space Syntax, where spaces are broken down into components and analyzed as networks of choices, describing the relative connectivity of those spaces. In this investigation, both external and internal conditions are studied and combined under the same formal analysis method. This allows us to find new patterns and connections resulting from this combinatorial analysis.

\section{Concepts definition}

Two descriptive criteria are considered: external boundary and interior conditions. We diagrammed the entire samples according to these criteria, and identified them by a code (Table 1).

\subsection{External boundary}

For the external boundary the interior space information is systematically discarded in order to emphasize the shape, as a figure-ground diagram. For the creation of these diagrams, secondary elements such as exterior open galleries or small walkways are not considered.

The analysis has been realized according to the following concepts: Regularity, orthogonality, axiality and straightness (Table 2). What follows is a description of each concept:

- Regularity: This paper follows Ching's definition of regularity, where "regular forms refer to those whose parts relate to each other in a consistent

Table 4 External boundary types - Museums plans represented at several scales (Table 5)

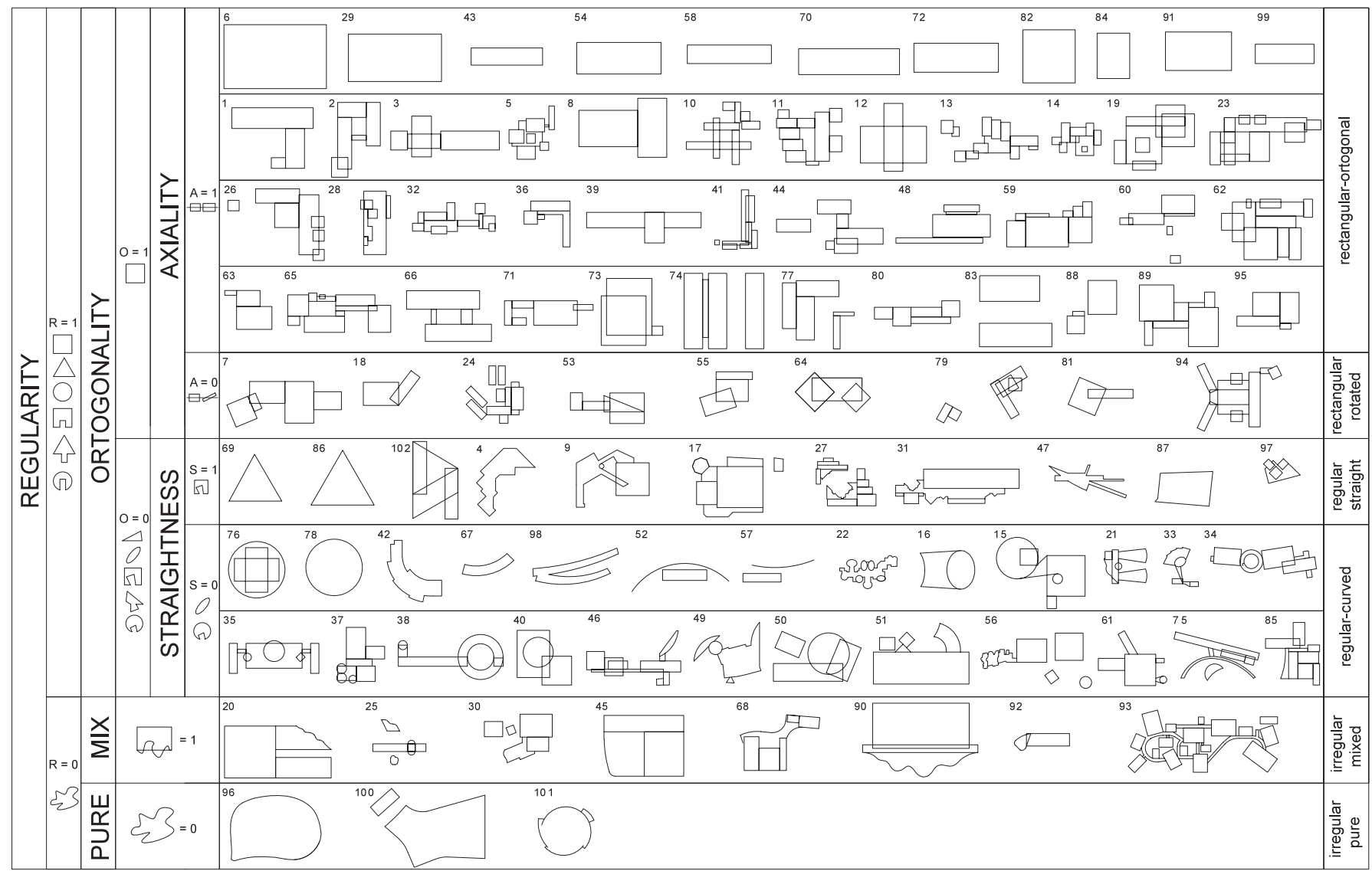


and orderly manner. They are generally stable in nature and symmetrical about one or more axes. [...] Forms can retain their shapes even when transformed regularly dimensionally or by addition or subtraction of elements" ${ }^{\prime 2}$. Ching also explains regularity from an experiential point of view when we can construct mentally the original whole of a form even when fragments are missing or added. In this study, regular forms refer to square, triangle, circle and oval simple forms, or composed by addition or subtraction of them. Irregular forms are those whose parts are dissimilar in nature or composed by other forms different to the regular ones. They are usually free-form and flowing in appearance. In this paper we called them mix irregular forms if they are composed of a regular form with some irregular form element or part. On the other hand, the ones that are totally irregular are called pure irregular forms.

- Orthogonality: Two types of regular forms can be distinguished: The cases where the reconstruction of the whole form is made of combination of one or more rectangular or squared shapes are defined as orthogonal examples. Non-orthogonal examples are characterized for being formed by regular shapes whose internal angle are different to 90 degrees, such as trapeziums, or regular curve forms such as circles or ovals.

- Axiality: Axiality defines the rotation of elements and a main axial direction. For the group of cases whose elements are defined as regular and orthogonal there are some of them with axiality following the main axis and others where the elements interact with turns (non-axial).

- Straightness: For non-orthogonal forms, there's still one more characteristic to consider: The presence of curved elements. Straightness in the cases is related to the presence or absence of curve parts in the boundary configuration. Cases are subdivided into two categories: those whose boundary is composed by straight sections and those that include curved parts.

\subsection{Interior conditions}

For the interior conditions, not only the shape of the spaces is relevant, but also the program and the connections between them. In this study we have developed programmatic diagrams, distinguishing three different areas: areas for private use restricted to public access, such as office or storage (r); areas for public services, such as cafeteria, auditorium or library (p); and areas for exhibition spaces or galleries (e) (Fig. 3 and Fig. 4).

The plan is diagrammed according to the layout and the sequence (Table 3). The layout refers to a way of organization, independent of the size. Sequence is the connections between spaces, the order of spaces depending on the area use.

Comparing the layout, five different groups are defined (A to E). A

Table 5 Museums plans represented at several scales

\begin{tabular}{|l|l|}
\hline Scale & No. case \\
\hline $1: 2.000$ & $69,84,99$ \\
$1: 5.000$ & $1,2,3,6,9,15,16,17,18,20,21,22,25,27,29,32,33,39,40,43,46,55$, \\
& $57,58,61,62,63,64,67,70,73,80,81,86,87,91,92,93,96,100,101,102$ \\
$1: 7.500$ & $7,8,14,30,31,36,37,38,42,44,46,47,50,51,53,56,59,71,72,77,79$, \\
& $82,94,95,97,98$ \\
$1: 10.000$ & $4,12,13,23,26,28,34,52,54,60,65,74,76,83,90\urcorner$ \\
$1: 15.000$ & $5,19,24,35,41,48,49,66,68,75,78,85,88,89$ \\
$1: 20.000$ & 10,11 \\
\hline
\end{tabular}

and $\mathrm{B}$ are differentiated for been isotropic spaces. Isotropy is uniformity in all orientations. By contrast, anisotropy cases (C, D and E) are those in which space properties are directionally dependent. Layout $\mathrm{C}$ has a central distribution. $\mathrm{D}$ and $\mathrm{E}$ have a hierarchical distribution for the areas depending on the use. In D cases the program distribution attends to the program separating exhibition spaces from public spaces. For E cases, the public space acts as a link between exhibition spaces.

Interior conditions in terms of shape and position are defined by the terms above. But there's still one more parameter to consider: the connections between spaces expressed with arrows in Table 3 . The cases are also classified attending to the circulation sequence from the main entrance to the exhibition space. We consider the sequence independent from the layout configuration. The layout attends to the main distribution of spaces, while the sequence is defined through the visitor movement from the entrance to the exhibition spaces. Among the analyzed cases, 87 cases have the entrance at the same floor as the exhibition spaces. In the 15 cases where the chosen plan does not coincide with the access floor, we consider the floor main access point (such as stairs, ramps or elevator) as the sequence start point. There are two sequence types as explain below:

Lineal sequence involves spatial connections where public and exhibition spaces are followed one by another (pe, pee, ppe, ppee, pepe). For example, in "ppee" pattern the access public space is followed lineally by another public space and two exhibition spaces. In some cases, exhibition spaces are connected by secondary spaces (pe.e).

Ramified sequence involves a clear hierarchy between public and exhibition spaces. The most common patterns are those such as comb (named as peC), herringbone (named as peI), and other branching formations (peV, peL, peS). Patterns named "peV" attend to a $V$ shape ramification, "peL" to an $\mathrm{L}$ shape ramification, and "peS" is used to describe other branching formation without any specific shape.

\subsection{Coding and examples}

Every case has been identified with a code notation composed by two parts separated by a dash. For example, the analysis of Example 1 (Fig. 3) is defined as "100-DLpee". The first part of the code represents the external boundary and the second part the interior layout and the sequence pattern.

A boolean notation is used as a compact way to code with two possible values: true (1) or false (0). The first digit of the code defines the regularity (regular forms $=1$; irregular forms $=0$ ). For the regular cases, the second digit defines the orthogonality (orthogonal forms $=1$; non-orthogonal forms $=0$ ). For orthogonal cases, the third digit defines the axiality (axial forms=1; non-axial forms $=0$ ). For non-orthogonal cases, the third digit defines the straightness (straight forms $=1$; non-straight forms $=0$ ).

For irregular cases, two digits form the code: The first digit (0) defines the irregularity, while the second digit indicates if it's an irregular mixed case (1) or irregular pure case (0).

The second part of the code (after the dash) describes the layout type (A, B, C, D or E) and the sequence pattern. The sequence pattern is only specified for the layouts C, D and E. For C layout cases, C1 (centrifugal) or $\mathrm{C} 2$ (centripetal) is specified. For D and $\mathrm{E}$ layout cases the sequence is specified as linear $(\mathrm{L})$ or ramified $(\mathrm{R})$ in the first letter, continued by the 
sequence order letters

For example, the analysis of Example 1 (Fig. 3) is defined by "100-DLpee" code. The first part of the code (100) defines the case in terms of external boundary; the second part describes a "D" layout and "Lpee" sequence pattern. Figure 4 shows an irregular case example with " $00-A$ " code (irregular pure case with an A layout).

\section{Arrangement}

\subsection{Compositional diagrams. Typologies based on external boundary}

In order to understand the external boundary, cases are divided according to their specific qualities and similar arrangement in terms of formal composition. In Table 4, concepts are shown in the left column and the result of the classification in the right column, distinguishing the following six different types:
- Rectangular-orthogonal type (code 111) is defined by their regularity, orthogonality and axiality and it represents the simplest shape boundary condition. The rectangular shapes are combined to create the whole composition of the plan (46 cases out of 102). Sometimes (11 out of 46) just one shape is enough to conform the whole building plan.

- Rectangular-rotated type (code 110) whose composition in plan is also based in rectangular forms, but the axiality is lost (9 cases out of 102)

- Regular-straight type (code 101) is formed by regular but non-orthogonal cases formed with rectilinear boundary composition (11 cases out of 102).

- Regular-curved type (code 100) is formed by regular but non-orthogonal cases including curved boundary elements (25 cases out of 102).

- Irregular-mixed type (code $0 \mathrm{M}$ ) present cases formed by irregular forms combined with regular parts (8 cases out of 102).

- Irregular-pure type (code $0 \mathrm{P}$ ) is composed by cases with organic form

Table 6 Interior condition layouts - Museums plans represented at several scales (Table 5)

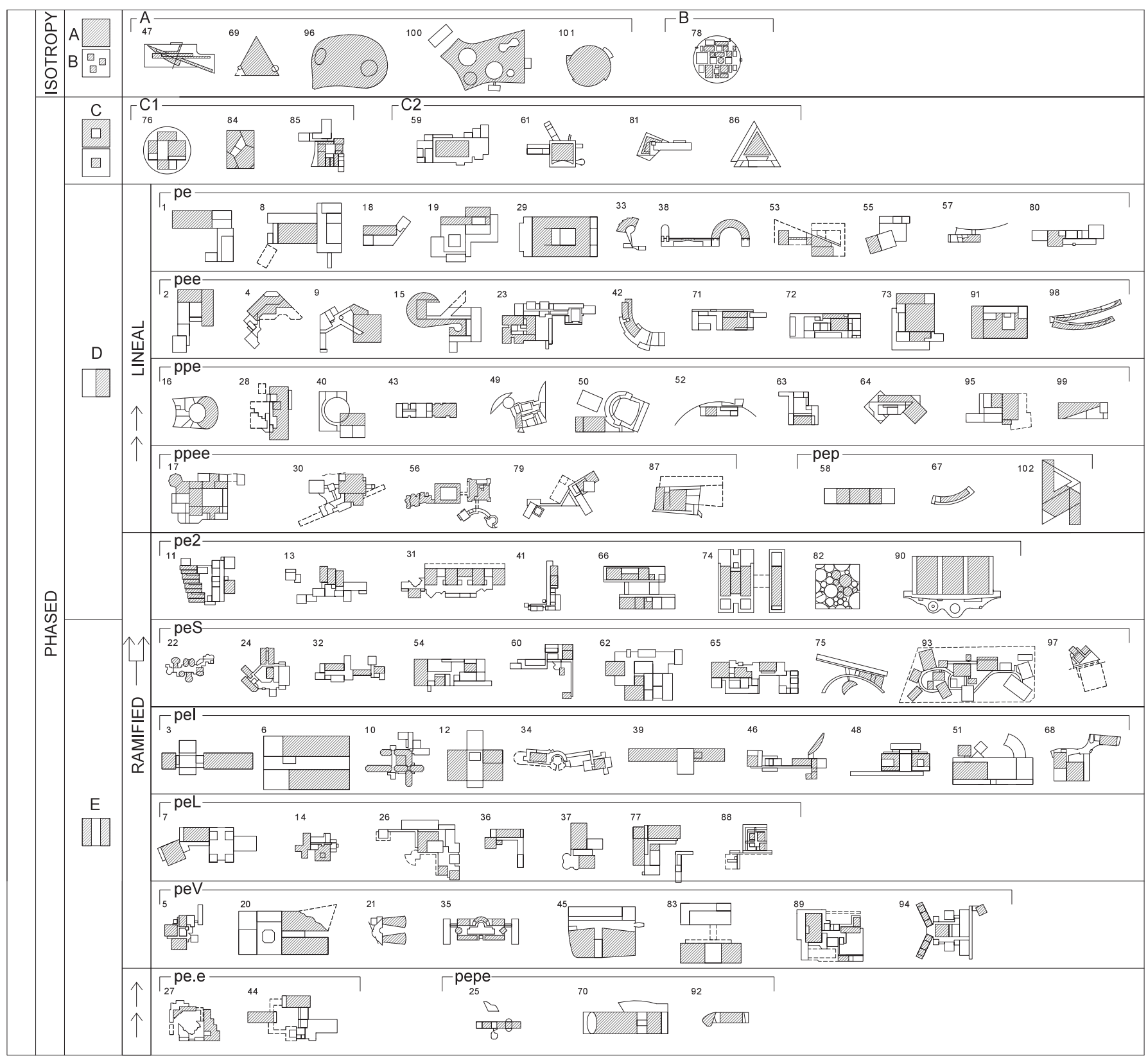


Table 7 Boundary-interior conections - Museums plans represented at several scales (Table 5)

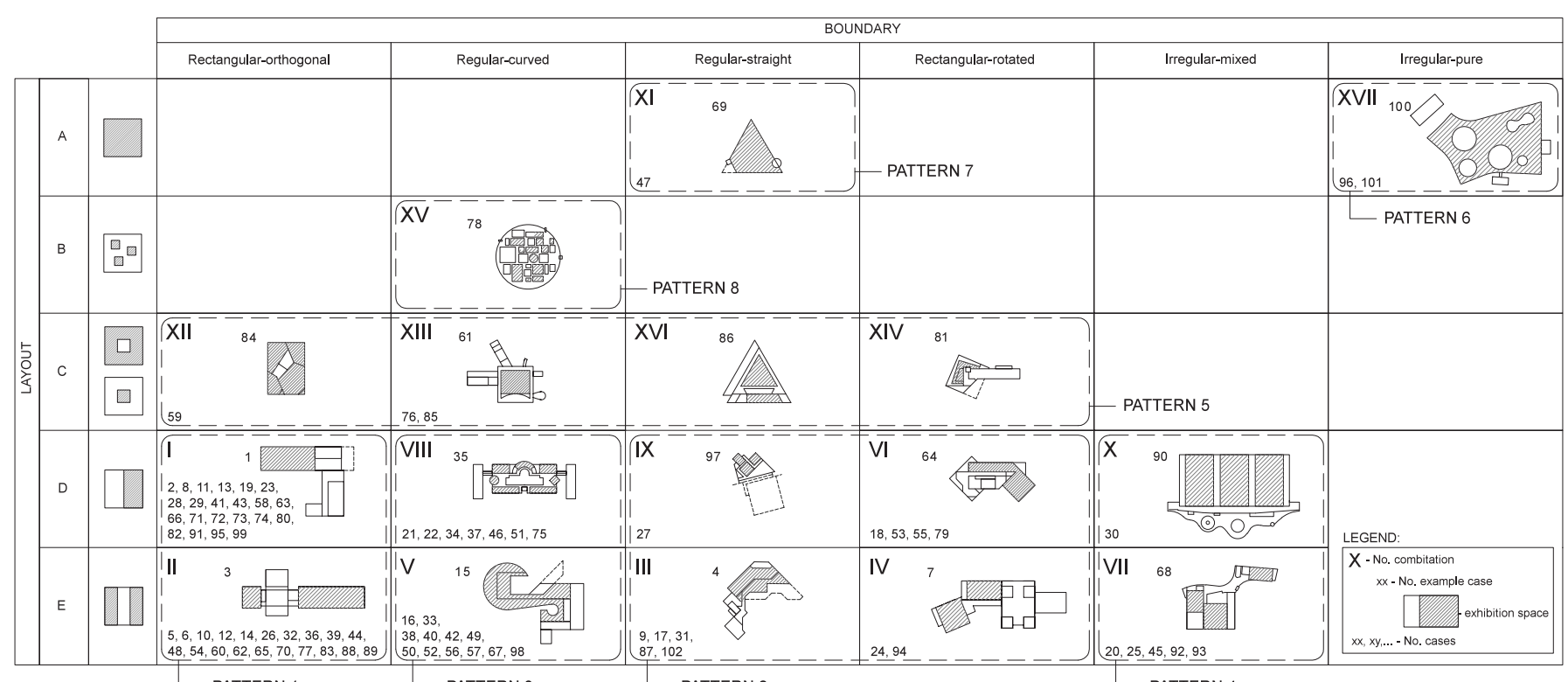

PATTERN 1

PATTERN 3

PATTERN 4

along the entire boundary (3 cases out of 11).

\subsection{Sequence diagrams. Typologies based on interior conditions}

As for the internal organization of the museums, cases are divided according to their specific qualities and similar arrangement in terms of interior layout and sequence. Concepts are shown in the left column of the Table 6 distinguishing two main groups:

Isotropy group (6 cases out of 102) is formed by cases where the layout presents an isotropy space configuration. Two different layouts are consider in this group:

- Layout A (5 cases out of 102) is formed by unitary small spaces.

- Layout B (1 out of 102) is formed by multiple exhibition spaces connected in a non-hierarchical way.

Phased group (96 cases out of 102) includes cases related to phased architecture sequence with a hierarchical formation layout. Three types are included in this group $(\mathrm{C}, \mathrm{D}, \mathrm{E})$. In D and E layout types, the classification in terms of sequence is specified within two subgroups: Lineal sequence and ramified sequence.

- Layout C (7 cases out of 102) is formed by central layout cases. In this type, the direction of the movement is described when talking about sequence. In this way, there are centrifugal cases where the exhibition space surrounds the public space $(\mathrm{C} 1,3$ cases out of 7) and centripetal cases where the public space surrounds the exhibition space (C2, 4 cases out of 7).

- Layout D (49 cases out of 102) is formed by cases with hierarchical layout, where the use of the areas is divided clearly in exhibition space and public space.

- Layout E (40 cases out of 102) is formed by cases with hierarchical layout, where the exhibition space areas are divided in two or more areas and connected by public space areas.

\subsection{Boundary-interior connections}

Once cases have been analyzed and classified based on their external boundary and interior conditions, the resulting typologies are combined as shown in Table 7. By creating a matrix, the classification for external boundary is related to the classification for interior layout. As a result, we obtain 17 combinations identified by a number from I to XVII (upper-left corner of each cell). Every combination is represented by an exemplary museum plan in order to provide an easier understanding.

As an overview, it can be shown that the combinations I and II are the most common. On the contrary, other combinations (IV, IX, X, XI, XII, XIII, XVII) have few cases (less than 3) or even just one simple case (XIV, $\mathrm{XV}, \mathrm{XVI})$. We can also identify combinations with quite numerous cases, such as V and VIII, that are not so common as the regular-orthogonal ones (combinations I and II), but still present D and E layouts, but with regularcurved external boundary.

\section{Discussion}

After the classification of the cases in the different combinations (table 7), we made a grouping of these combinations attending to their external boundary and interior layout. We call every group of combinations a "pattern". Given the results mentioned above, we first aim to suggest similar characteristics among combinations, in order to discuss later a possible understanding of their evolution in time.

\subsection{Patterns creation}

From the typology viewpoint, every pattern shows specific design strategies. The patterns characteristics are the following:

Patterns 1, 2 and 3 are related to a classical understanding of architecture and characterized for having a regular boundary and hierarchical layout. Pattern 1 is formed by cases with a rectangular-orthogonal external boundary and D or E layout, like in the Nagano Prefectural Shinano Art Museum (no.3). For this pattern, museums plan external boundary is composed by just one rectangle or a combination of several rectangles with 90-degree angles relation between them, presenting a simple constructive configuration. Pattern 2 is formed by cases with regularity and straightness (regular-rotated and 
regular-straight external boundary) and also presents D or E layout, like in the Kitakyushu Municipal Museum of Art (no.7). In pattern 2, the simplicity of the composition is based on straight lines external boundary, but including dynamism trough the use of axialities and shapes rotation. Pattern 3 is formed by cases with a regular-curved external boundary and D or E layout, like in Shiseido Art House (no.15). The characteristic of this pattern is the inclusion of curved elements in the external boundary. It has a simple constructive approach, but with a contemporary dynamic appearance.

Pattern 4 also shows a hierarchical layout (D or E), but with irregularmixed external boundary, like the Shimane Art Museum (no.68). For this pattern, cases present a contrast between organic and regular shapes in the external boundary.

Pattern 5 is formed by central layout cases, presenting several different external boundary type compositions (rectangular-orthogonal, regular-curved, regular-straight and rectangular-rotated), like for example the Kumano Kodo Nakahechi Museum (no.61). For this pattern, there is a project decision of creating directionality from and to the center of the proposal, an overall strategy to generate a centralized plan layout, but avoiding a strong symmetry. These cases have more dynamic boundary and an isotropical configuration, where the external boundary is less dominant.

Patterns 6, 7 and 8 have an isotropic layout, but with differences in their external boundary. Pattern 6 is formed by irregular-pure cases, presenting a non-hierarchical layout (type A) and composed by a single exhibition space as in the case of the Hiroshi Senju Museum of Karuizawa (no.100). Pattern 7 is formed by cases that also presents a non-hierarchical layout (type A) and composed by a unitary space, but with a regular-straight external boundary, as in the case of the Nemunoki Art Museum (no.69). Pattern 8 contains only one case (21st Century Museum of Contemporary Art, no.78), and it is a singular case formed by several exhibition spaces, presenting a regular-curved plan boundary and, at the same time, having a layout composition that suggest the release from hierarchical order.

\subsection{Timeline}

Finally, patterns are discussed in terms of time (Fig. 5). Cases are plotted along their pattern number timeline according to the year when they where built. A progression in the timeline can be noted, giving some clues about concepts evolution. As an overview, the results suggest a tendency for the use of irregular forms in the boundary conditions, allowing museums design became more dynamic.

The result shows that regular-orthogonal boundary type with static phased layout type (Pattern 1) prevails over time. This pattern includes early cases (e.g. Ishikawa Prefectural Museum of Art, 1959) and also recent ones

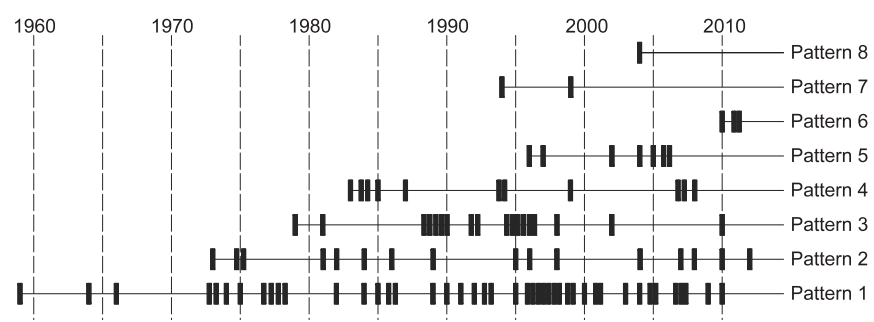

Fig.5 Timeline groups distribution (e.g. Akita Museum of Art, 2012).

Around the 1970s we noticed the emergence of cases involving changes at the external boundary (Patterns 2 to 8 ). In Pattern 2 the axiality of the plan is lost (e.g. Akino Fuku Museum, 1998), and in Pattern 3 there is an incorporation of the use of curve elements in the plan form (e.g. Yokohama Museum of Art, 1989).

From the 1980s, Pattern 4 appears involving more dynamic plan configurations through the use of irregular forms in the external boundary (e.g. National Art Center of Tokyo, 2007). There are also some regular boundary type museums that have been built in the last two decades showing a significant change with regard to the layout, having more dynamic layout compositions (Patterns 6 and 8).

In the 1990s, Pattern 5 comes out with a central layout and diverse external boundary forms. For example, Kanno Museum (2005) has a centrifugal central layout and rectangular-orthogonal external boundary. Another example of this pattern but with centripetal central layout and regular-curved external layout is the Kumano Kodo Nakahechi Museum (1997).

In the case of Pattern 6, museums as the Hiroshi Senju Museum of Karuizawa (2011) have appeared as irregular pure forms with an isotropic layout. The timeline shows how this irregular shape is the latest pattern for this research, and we can identify a tendency to irregular external boundaries and the use of isotropic interior layouts.

For Pattern 7 the isotropy of the interior layout is created by the unity of the space, as in the Nemunoki Art Museum (1999), and the regularity of the external boundary appears earlier than other isotropic patterns (6 and 8).

In the case of the Pattern 8 represented by the 21st Century Museum of Contemporary Art (2004), the building has a regular-curved external boundary, but the multiplicity of spaces within a non-hierarchical plan layout makes it different to other museums built in the same period, as for example the Kagawa Prefectural Higashiyama (2004).

When we compare these patterns, we can find some relations and contrast between them. The comparison between Patterns 1 to 4 indicates that, within the same static and phased layout (D or E), an evolution through time from regular to irregular shapes can be noted. Whereas the characteristics of rectangular-orthogonal boundary found in Pattern 1 continues over time, cases with irregular boundary are appearing during the last years of the timeline. This means that some cases, even if they follow the tendency on external boundary for including irregular forms, the layout configuration remains static according to the previous years patterns. For example, case 20 (The Museum of Modern Art of Saitama, 1983) presents an irregular-mixed external boundary and E layout. By contrast, some of the regular boundary type museums that had been built in the last two decades (Patterns 5, 6 and 7) show a significant change with regard to the layout and have more dynamic interior conditions (A, B and C layout types). For example, case 84 (Kanno Museum, 2005) has a regular-orthogonal external boundary and a C1 layout.

For the cases built in the last years (Patterns 6, 7 and 8), there is not still enough information due to the lack of cases. We do not know if the configurations of these museums will continue in future projects, but we can notice the intention of several architects to innovate in the creation of new architectural expressions by introducing new plan configurations. 


\section{Conclusions}

This study takes 102 post-war Japanese art museums as a sample to analyze some of the characteristics of contemporary Japanese architecture and its evolution. After the Second World War, the Japanese socio-economical context allowed architects to develop new ways of expressing ideas, sometimes through the use of new forms in the external boundary, sometimes through the design of more dynamic interior conditions. We chose these two aspects (external boundary and interior conditions) as the base for our analysis. The goal is to clarify the formative ideas and the architect's intentions by building a taxonomy and an evolution analysis of post-war Japanese art museums based on the plan as a parti diagram.

For the external boundary, we defined four different concepts: Regularity, orthogonality, axiality, and straightness. From these concepts we obtained six types: Rectangular-orthogonal, rectangular-rotated, regular-straight, regular-curved, irregular-mixed, irregular-pure. For the interior conditions we defined two concepts: Layout (isotropy and phased) and sequence (lineal and ramified). From these concepts we obtained five layouts: A, B, C, D, E.

Finally, by crossing these two sets of concepts in a matrix and finding their relations we suggest eight patterns. Patterns 1, 2 and 3 are characterized for having a regular boundary and hierarchical layout. Pattern 4 also shows a hierarchical layout, but with irregular-mixed external boundary. Pattern 5 has a central layout with diverse external boundaries. Patterns 6,7 and 8 share an isotropic layout. Pattern 6 contains a unitary exhibition space with irregularpure external boundaries. Pattern 7 contains a unitary exhibition space with regular-straight external boundaries. Pattern 8 (the 21st Century Museum of Contemporary Art) is formed by several exhibition spaces with regularcurved external boundary.

When we consider these patterns trough their evolution in time we can identify some tendencies. Regular-orthogonal boundary with static phased layout (Pattern 1) prevails over time. In Patterns 2, 3 and 4 the changes in the external boundary appear gradually through time. There are also some regular boundary museums built in the last two decades (in Patterns 5, 6 and 7) that show central or isotropic layouts, which differ from early patterns. The timeline analysis suggests a tendency towards irregular external boundaries and the intention of finding non-hierarchical plan layouts. This tendency might be interpreted as the architects' response to new ways of enjoying art - with more free and dynamic circulations - and also with the new role of museums as urban icons in Japanese cities.

The aim of this paper was to obtain an overall view of multiple cases using abstract concepts that allowed comparison and analysis. In further studies we also want to study specific cases within each pattern, and the circumstances surrounding the conception and design of the most representative cases.

\section{Acknowledgment}

I would like to give special acknowledgements to Ayaka Sakai, Koutaro Sato and Ryo Kawai, for their contribution to this study.

\section{References}

1) Botond Bognar: Beyond the bubble: the new Japanese architecture, Phaidon Press, 2008.
2) Arata Isozaki: Japan-ness in Architecture, The MIT Press, 2011.

3) Alexander Klein: Vivienda Mínima: 1906-1957, Editorial Gustavo Gili, 1980

4) Christopher Alexander: A Pattern Language: Towns, Buildings, Construction, Oxford University Press, 1977.

5) Peter Eisenman: House X, Rizzoli, 1982.

6) John Hejduk: Three Projects. 1962-66, Architectural Design, vol. 54, no. 11/12, 1984.

7) Sakamoto K, Tsukamoto Y, Iwaoka T, et al.: 建築構成学-建築デザインの方法. (Architectural composition studies - method of architectural design)実教出版, 2012.

8) Chris Van Uffelen: Contemporary museums: architecture, history, collections, Editions Braun, 2011.

9) Brutus Magazine: 100 Museums in Japan, Casa Brutus, 2013.

10) Kunio Nakai, Chiharu Moriyama and Kazunari Sakamoto: Esterior Spatial composition and conditions of location of contemporary Japanese museums, Journal of Architecture, Planning and Environmental Engineering (Transactions of AIJ), no. 607, pp. 33-40, 2006.9.

11) Shihoko Koike and Osamu Nakagawa: Using space syntax to clarify spatia configurations in Japanese public museums, Journal of Architecture, Planning and Environmental Engineering (Transactions of AIJ), vol. 76, no. 662, pp. 851-857, 2011.4

12) Francis D. K. Ching: Architecture: Form, Space, and Order, John Wiley \& Sons, Inc., 2007. 


\section{和文要約}

本研究では日本の現代建築の特性と歴史的な变遷の一端を分析寸 るために、102の日本の戦後の美術館建築をサンプルとして抽出した。 第二次世界大戦後、日本の社会経済状況により建築家たちは新しい 形の外部境界やダイナミックな内部条件の設計を通して、新しい表 現方法を発展させられるようになった。ここでは、外部境界と内部 構成の 2 つの軸に着目し、分析を行った。平面構成に基づいた「パ ルティ」ダイアグラムを用いた戦後日本の美術館について類型を行 い、時代ごとの変遷を分析することで、建築家の設計意図や美術館 の造形に対する考えを明らかにすることを目的とする。

外部境界として regularity（規則性）、orthogonality（直行性 ）、axiality（軸性）、straightness（直線性）の 4 つの概念を抽出し、 ここから rectangular-orthogonal (長方形・直行性)、rectangularrotated (長方形・回転性)、regular-straight (規則性・直線性)、 regular-curved ( 規則性・曲線性)、irregular-mixed (不規則・混 合性 )、irregular-pure ( 不規則・単体性 ) の 6 タイプに分類した。 内部構成では layout(配置)——isotropy（等方性）と phased( 段階性)—と sequence（シークエンス）—1ineal（直線性）と ramified ( 分岐性) 一一に着目し、A〜Eの 5 つのタイプに分類した。 これらを 2 軸としてマトリクスにまとめ、その関係を考察すること で 8 パタンに分類した。パタン $1 、 2$ 及び 3 は規則的な境界とヒエラ ルキーのある配置が特徽である。パタン 4 もヒエラルキーのある配 置であったが、不規則で混合した外部境界が見られた。パタン 5 で は求心性のある配置で多様な外部境界を持っている。パタン $6 、 7 、$ そして 8 は等方性の配置であり、パタン 6 は、不規則で単体の外部 境界を持つ単一の展示空間が見られた。パタン 7 は、規則的で直線 の外部境界を持つ単一の展示空間が見られた。パタン 8 (21 世紀美術 館）は規則的な曲線の外部境界を持ち、複数の展示空間で構成され ていた。

これらのパタンを時代の変遷を通して考察すると、いくつかの 傾向が見られた。段階的な配置で規則的で直交の境界をもつパタン 1 は、ぞの時代でも建てられている。パタン $2 、 3$ そして 4 では外部 境界が時代とともに徐々に変化している。パタン 5、6、そして 7 の ように、最近 20 年間に建てられた規則的な境界を持つ美術館は、戦 後直後に建てられたものと違い、求心性、等方性の配置が見られた。 これらの時代ごとの分析は、不規則な外部境界への傾向とヒエラル キーのない平面構成への意図を提言している。この傾向は、より自 由で、ダイナミックな動線を持つという、美術を楽しむ新しい方法 への建築家の答えであると同時に、日本における都市のアイコンと しての美術館の新しい役割となっていると考えられる。

本論文では、複数事例の比較分析を可能とする抽象的な概念 を用いた全体像を得ることを目的とした。さらに今後の展望として、 各パタンや最も代表的な事例の起源やデザインを含んだ状況につい てより詳細な分析に発展させることができるだろう。 